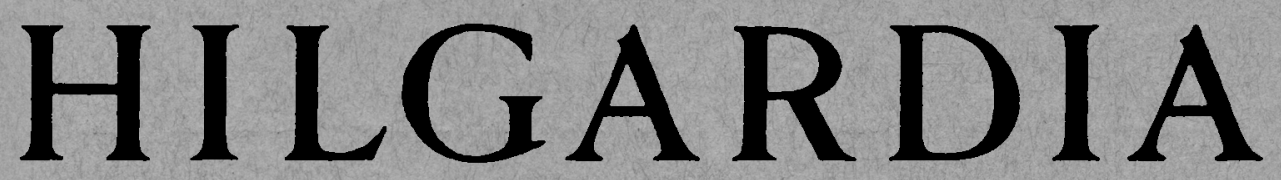

A Journal of Agricultural Science Published by the California Agricultural Experiment Station

\title{
DIVERSITY AMONG NUCELLAR-SEEDLING \\ LINES OF SATSUMA MANDARIN AND DIFFERENCES FROM THE PARENTAL OLD LINE
}

HOWARD B. FROST, JAMES W. CAMERON, and ROBERT K. SOOST 
Nucellar embryos are produced asexually, from somatic cells of the nucellus. Usually, therefore, nucellar seedlings reproduce the genotype of the seed parent. Nongenetic differences from the seed parent occur as transient juvenile characteristics, and also sometimes result from elimination of disease viruses.

Budded descendants of nucellar seedlings of one seed-parent Satsuma tree have been studied in two propagated generations, in eighteen crop years. Trees of the first generation, budded directly from different nucellar seedlings, commonly differed so consistently in fruit shape as to indicate considerable probability of genetic diversity.

From two of these budded trees, which differed in fruit shape and also in leaf size, trees were budded for small plots. These plots differed sig. nificantly in tree form and leaf size, and in yield, shape, and time of coloring of fruit.

The tree types of these two nucellar-line strains were identified repeatedly among sister nucellar seedlings. Tree characters and fruit shape have indicated that at least one or two other genetic types probably were present among nucellar seedlings of the same seed-parent tree. That tree probably either included several genetic types, or produced genetic variations during formation of nucellar embryos.

One seedling type, probably of nucellar origin, which occurred only once among several hundred seedlings, differed conspicuously in tree and fruit.

A plot of old-line trees, budded directly from the seed parent of the nucellar seedlings, has been inferior to both nucellar-line plots in size of trees and leaves, in yield and time of coloring of fruit, and in percentage of soluble solids and solids/acid ratio of juice. The greater yield of the nucellar lines has been due mainly to their greater tree size. Earliness of fruit coloring has shown marked positive correlation with yield.

The better of the two nucellar lines of the plots (strain A) is recommended for trial in climatic conditions favorable to the Satsuma, especially in some navel orange districts.

Observation and tests have indicated absence of the psorosis and tristeza viruses from both seed-parent and nucellar lines. 


\title{
H I L G A R D I A
}

A Journal of Agricultural Science Published by

the California Agricultural Experiment Station

\section{DIVERSITY AMONG NUCELLAR-SEEDLING LINES OF SATSUMA MANDARIN AND DIFFERENCES FROM THE PARENTAL OLD LINE ${ }^{1}$}

\author{
HOWARD B. FROST ${ }^{2}$, JAMES W. CAMERON ${ }^{3}$, and ROBERT K. SOOST ${ }^{4}$
}

\section{INTRODUCTION}

Satsuma is the usual name in the United States of several similar strains ${ }^{5}$ of citrus that are included in the very diverse mandarin group (Citrus reticulata Blanco; Swingle, p. 413, and Webber, p. 550, in Webber and Batchelor, 1943). ${ }^{\circ}$ These strains are often called Satsuma orange, commercially and by various writers (Tanaka, 1932; Webber, in Webber and Batchelor, 1943), but their great differences from the sweet oranges make this name rather misleading. The term Satsuma mandarin is also used. The Satsuma is the principal citrus fruit of Japan, where its standard name is Unshu mikan. In the United States, because of its adaptation to a relatively cool climate, it has had some commercial importance in several Gulf states, principally Alabama and Florida, but freezes have mostly eliminated it. In California it has not been extensively grown, largely for climatic reasons; it is intolerant of hot desert conditions, and in the cooler districts it colors somewhat later than the earliest desert-grown mandarin varieties.

Tanaka (1932; summary given by Webber, p. 550 in Webber and Batchelor, 1943) has reported very extensive studies of the Satsuma in Japan, where various named strains are known to growers. He shows that numerous strains have arisen by bud variation. One that has arisen repeatedly is the widely cultivated Wase, with comparatively large and early ripening fruit. This strain has often reverted to the parent Owari strain, and such variation may have contributed to some uncertain results of trials with Wase in California.

Tanaka $(1932$, p. 39) states that although the botanical characteristics of the Satsuma are predominantly those of the mandarin group, there is some

\footnotetext{
${ }^{1}$ Paper No. 937, University of California Citrus Experiment Station, Riverside, California. Received for publication November 2, 1956.

${ }^{2}$ Associate Plant Breeder, Emeritus, in the Experiment Station, Riverside.

${ }^{3}$ Associate Geneticist in the Experiment Station, Riverside.

${ }^{4}$ Associate Geneticist in the Experiment Station, Riverside.

"The term "strain" is here employed, as by A. D. Shamel, to designate genetic types that are known or supposed to have been differentiated, within a clonal variety, by somatic or bud variation.

"See "Literature Cited" for eitations, referred to in the text by author and date.
} 
resemblance to the sweet orange. He says that several citrus varieties of Japan and the adjacent mainland seem closely related to the Satsuma; two of these are the Kunembo and the King, which appear to be interspecific hybrids between $C$. sinensis and $C$. reticulata (Swingle, p. 414 in Webber and Batchelor, 1943). Tanaka suggests that the Satsuma may have arisen as a single variant seedling. If so, it might well have resulted from interspecific hybridization. In view of the high pollen sterility of the variety (Tanaka, 1932, pp. 40, 582 ; Frost, pp. 790, 810, in Webber and Batchelor, 1943) its present diversity may have developed entirely by somatic variation.

The present paper describes tree and fruit characteristics in young nucellar-seedling lines ${ }^{2}$ of Satsuma (fig. 1), mainly in the first and second budded generations descended from seedlings of one old seed-parent tree. Data on the old parent line are included in many comparisons. The work is part of a wider study of nucellar lines, including genetically variant forms which may arise among nucellar seedlings of identical parentage. Evidence of the general behavior of several nucellar lines has been recently reported (Batchelor and Cameron, 1949 ; Frost, 1952 ; Cameron and Soost, 1952). Older evidence has been presented and hypotheses discussed by Hodgson and Cameron (1938) and Frost (1938; pp. 818-832 in Webber and Batchelor, 1943). Swingle (1932) seems to have been the first to report that nucellar embryony produces conspicuous modifications, other than the well-known thorniness of seedlings, in old clonal varieties of citrus. Swingle and Robinson (1931) introduced a nucellar line of Satsuma as a promising strain, the Silverhill.

There are several reasons for expecting that nucellar-line peculiarities will differ irregularly in kind, amount, and persistence. Juvenile characteristics not resulting from elimination of viruses in seed formation, such as thorniness, are of limited but variable duration; elimination of seed-parent viruses should be effective as long as reinfection does not occur; and a genetic variation may be stable or unstable.

\section{MATERIALS AND EXPERIMENTAL METHODS}

This study is based mainly on two nucellar-seedling lines that were initiated by two seedlings of a tree designated RT64, and on comparable old-line trees budded directly from that seed parent. This was a tree supposedly of the Owari strain of Satsuma, obtained from a commercial nursery and planted, probably in 1907, in the variety collection of the Citrus Experiment Station on its former Rubidoux Tract, in Riverside. Other nucellar lines have been less extensively studied, including two derived from seeds of RT1170, a tree which had been budded from RT64 (see tables 2 and 3). All but two of the nucellar lines reported in this paper were obtained from seeds that developed after guarded pollination with varieties very unlike the Satsuma, in 1915 and 1916. The other two (trees B30,50 and B30,54; see tables 2 and 3 ) were from open pollination of RT64 in 1915.

\footnotetext{
${ }^{7}$ The term "nucellar-seedling line" is used to designate the trees in an exclusively propagational (budded) line of descent from any one nucellar seedling (Frost, 1952). Since nucellar embryos arise by proliferation of somatic cells of the nucellus (as "nucellar buds"), all nucellar lines from any one seed-parent form (genotype) are genetically identical, unless genetic bud variation has occurred.
} 

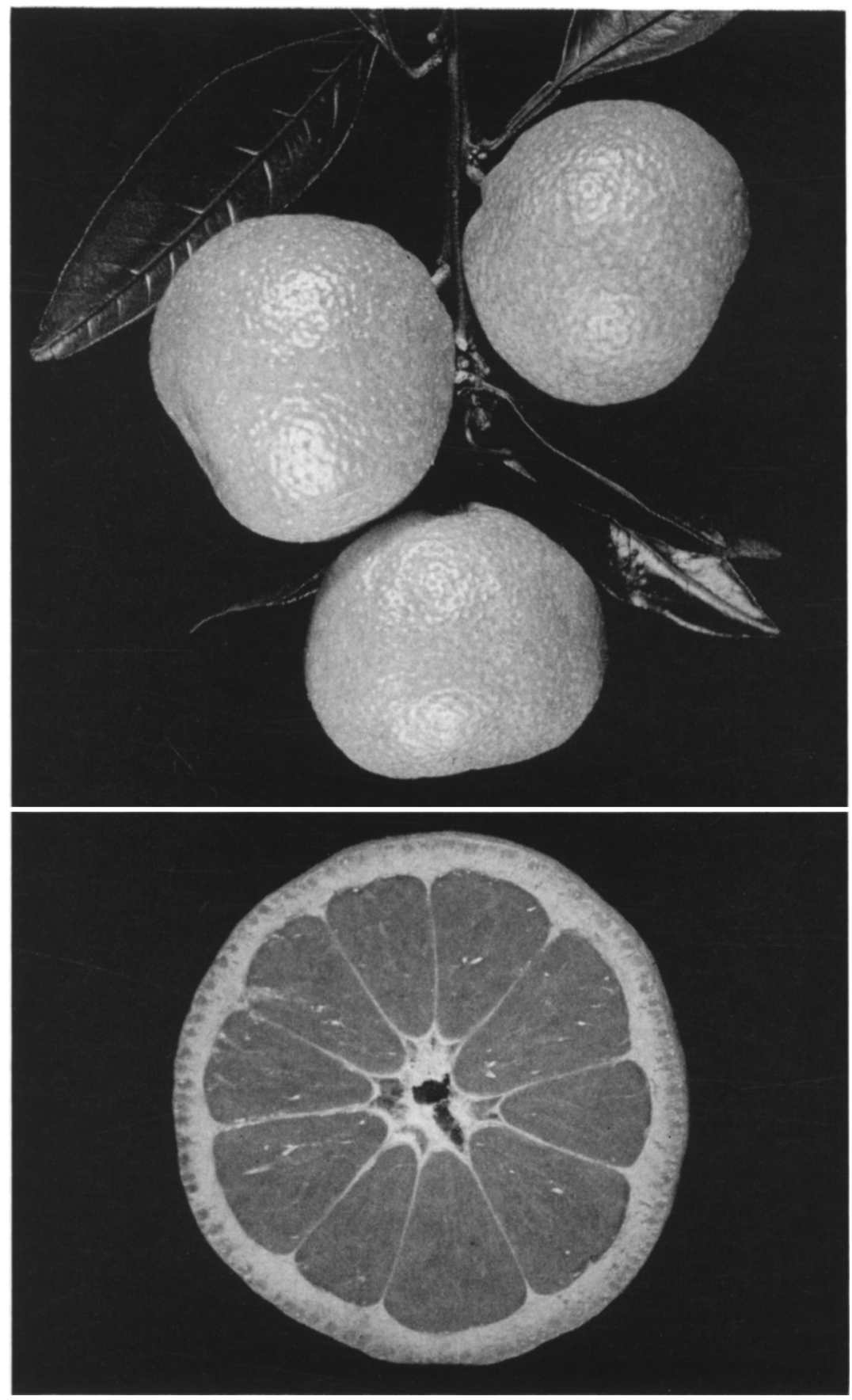

Fig. 1. Fruits of the Satsuma mandarin, from nucellar line 1 (strain A) as grown at Riverside. These fruits were about two inches in diameter. 
Trees of the Primary Trial. This trial, in field 2 at the Citrus Experiment Station, included one budded tree from each of 22 nucellar seedlings, on trifoliate-orange (Poncirus trifoliata) rootstock. These trees were chosen from a much larger number of nucellar-line trees from the same two seed parents, all of which had been examined for, recognizable genetic variations. One lateripening variant tree was found and is described in this study ; the other trees were taken partly because of comparatively flat or deep fruit shape, and partly in serial order of row location without reference to indications of possible genetic difference.

All the trees of this trial represented in the tables had been set in the orchard in 1920 (rows B29 and B30) and 1922 (row B52), with these two exceptions: $\mathrm{B} 30,18$ was planted two years later, and B30,40, three years later than the neighboring trees studied.

These trees were usually at $10^{\prime} \times 12^{\prime}$ spacing. They had been planted 5 feet apart in the row, and thinned in 1926 (rows B29 and B30) and 1927. The place numbers of the trees in the tables therefore show the distances between compared trees. The spacing and care were adequate for young Satsuma trees on trifoliate rootstock; throughout the primary trial (1926-1936) they were vigorous and productive.

Trees of the Secondary Trial. The trees for the main portion of this trial were propagated on Cunningham-citrange rootstocks in 1930, and were planted in 1932 in two adjacent rows in a field (S1) distant from the primary trial. There are three plots, budded respectively from the old-line seed parent, RT64, and from two of the nucellar-line trees of the primary trial (see table 4). The place numbers of the trees are as follows: in row G3, places 6 to 15; in $\mathrm{G} 4$, place 6 . The planting distance was $18^{\prime} \times 18^{\prime}$, with the plots surrounded by trees of somewhat similar size. Each plot was planted with the four largest trees of six that had been budded (Frost, 1952), except that from the oldline parent only three trees were available.

One year earlier (1931), a few of the original nucellar seedlings were planted in the two rows immediately preceding the plots. These trees, from a crowded and hedge-pruned planting of seedlings, were not greatly larger at orchard planting than were the budded trees of the plots in 1932 ; they are now (1956) considerably larger than the budded trees.

In this trial, as also in the primary trial, fruit production was not affected by pruning, which was almost entirely limited to removal of occasional broken branches.

Tree Measurements. Trunk cross-section areas were calculated from circumferences, measured $7 \mathrm{~cm}$ above the bud union. Leaf size was determined from samples of 50 leaves each, taken by clipping twigs with leaves of approximately maximum size, no leaves being taken separately. All samples were taken from the same side of the tree, with similar exposure to light.

Sampling of Fruit. Each sample was usually picked all around the lower part of the tree, which, with the nucellar lines at least, tended to bear the heavier and more uniform crop. The aim was to secure an unselected sample, except for avoidance of occasional fruits that were abnormal in size or condition.

In the primary trial, sample size for fruit-shape measurements was 20 
fruits per tree in 1926 and 1928, and 40 to 80 fruits in 1927. In 1929 to 1934 it was 50 or 60 scattered fruits, and also 100 fruits from clusters of three or more fruits each, measured as separate samples. In 1935 and 1936 it was 100 clustered fruits. Some trees of table 3 were necessarily omitted, partially or entirely, from the 100-fruit sampling, and in 1934 and 1936 a few samples were smaller because of low yield.

In the secondary trial the sample size for shape and weight was 20 fruits, except as follows: 100 fruits in 1939; 50 fruits in 1940 and 1943; and two samples of 40 fruits each in 1953 and 1954. From 1947 on, these samples were used also for composition analyses, with additional samplings for this purpose in 1953 and 1954.

Fruit Measurements. The fruits were measured in rows of 10 or 20, to obtain the quotient of the total transverse diameter of each sample by the approximate total axial diameter (the often-tapered bases of the fruits tended to "nest" in the apical basins of adjacent fruits). This quotient is called the fruit-shape index. This method of measurement has been found to give essentially the same differences of sample indices as are obtained by averaging individual-fruit indices. The latter procedure was used for table 8 . Each sample was weighed at the time of measuring.

Fruit-rind coloring was classified by separating all the fruits of each tree into two groups, respectively considered as more or less than 70 per cent colored. This separation took into account both depth and distribution of orange color. Although the line of separation was not exact, there was no doubt that the proportions in the two groups reflected very real differences among trees. The percentage was calculated from group weights in 1947, but thereafter from the numbers of fruits; these methods usually gave identical results.

Soluble solids were determined with a refractometer, on the basis of the refractive index of sucrose solutions (in 1947, with a hydrometer calibrated for sucrose). Acidity was measured by titration with sodium hydroxide and expressed as citric acid.

\section{STATISTICAL PROCEDURES}

Tests of Significance. The tests for the significance of the differences of means present the two-way probability (P) from Student's (1925) table of $t$, except that the normal-curve table was used for table 3 , where the number of degrees of freedom was fairly large. For fruit-shape index and for yield, the variates or annual means were paired to eliminate the annually correlated variation from the standard errors; elsewhere pairing was not used. For fruit yield, rind coloring, and soluble solids, where the three plots concerned appeared to differ in variability, the standard errors were based on the variance of each two plots being compared. With the other data, the pooled sum of squares related to each series of compared means was used to obtain a single error variance for all comparisons.

Unequal Sampling. Although the annual means for fruit shape and weight often represented different numbers of fruits, they have been given equal weight in calculation of general means and in tests of statistical significance of mean differences. Also, within years, "scattered" and "clustered" 
samples have been given equal weight in calculating annual means, although the two kinds of sample consisted of different numbers of fruits. This has been done to insure, as nearly as possible, equal representation of the different growth conditions of different years and of different spacing of fruits on the tree. To test the possibility that this procedure may have permitted sampling fluctuations of small samples to obscure more significant values of larger samples, some statistics (see tables 2 and 7 ) were recalculated, each sample index and annual-mean index being weighted with the respective number of fruits.

Since clustered and scattered fruits tended to differ systematically in fruit-shape index, annual pairing for fruit shape, for table 3, where some trees lacked the clustered sample, was always done with the same type of sample. To obtain a stable basis of comparison for the trees of table 3, a "high-standard" and a "low-standard" annual-mean index was calculated, for each year, from the annual means of the three high-index and the three low-index trees of table 2. For the years of dual sampling, each standard index was calculated both with and without the index of the clustered sample. Each annual-mean index of each tree of table 3 was then compared with the standard indices obtained by the same method of sampling. This was done to give, for each compared tree, two series of annual shape indices: (1) actual annual differences of shape index from the two standards, and (2) annual shape indices expressed as percentages of the two standards. Table 3 gives, for each compared tree, the general means of the percentage series, and the $\mathrm{P}$ value of the differences of the actual general means.

\section{RESULTS}

Results in the Primary Trial. There was rather extreme biennial alternation in yield throughout this trial: in the odd-numbered years the fruits were very numerous, and consequently small; in the even-numbered years they were comparatively few, and commonly averaged about twice as large. Occasionally, in "off" years, adequate samples could not be obtained from all trees.

Table 1 gives weights and shape indices of fruits, during nine years, for two Satsuma trees budded from two nucellar seedlings of the same seed parent. The fruit-shape indices show that in every year the fruits of tree B29,69 averaged flatter than those of tree B30,14, although the amount of difference was variable.

The indices for both trees were usually much higher in the odd-numbered years of heavy crop than in the alternate light-crop years. This difference was partly due to the more frequent development of a neck in the larger fruits of light-crop years. The shape indices of both trees were exceptionally high in 1927, among the years of heavy yield ; they were similarly exceptional in 1934, among the light-yield years. This was also true of the two other pairs of trees reported in table 2, discussed below. Altogether, it is clear that the shape of the Satsuma fruit is very susceptible to influence by conditions of growth. However, the usual close similarity of fruit size within single years, in these and other trees in this trial, associated with similarity in yield, suggests that the shape differences shown in table 1 were largely genetic. 
Inspection of the leaves during this trial indicated that B29,69 had larger leaves than B30,14.

Table 2 includes the trees of table 1, and gives data for two other selected pairs of nucellar Satsuma trees which also had consistently unlike fruitshape indices. The fruit weights of the two trees of each pair agreed well

TABLE 1

PRIMARY TRIAL. ANNUAL SHAPE INDEX AND WEIGHT OF FRUITS OF TWO SATSUMA TREES BUDDED RESPECTIVELY FROM TWO NUCELLAR SEEDLINGS OF SEED-PARENT TREE RT64

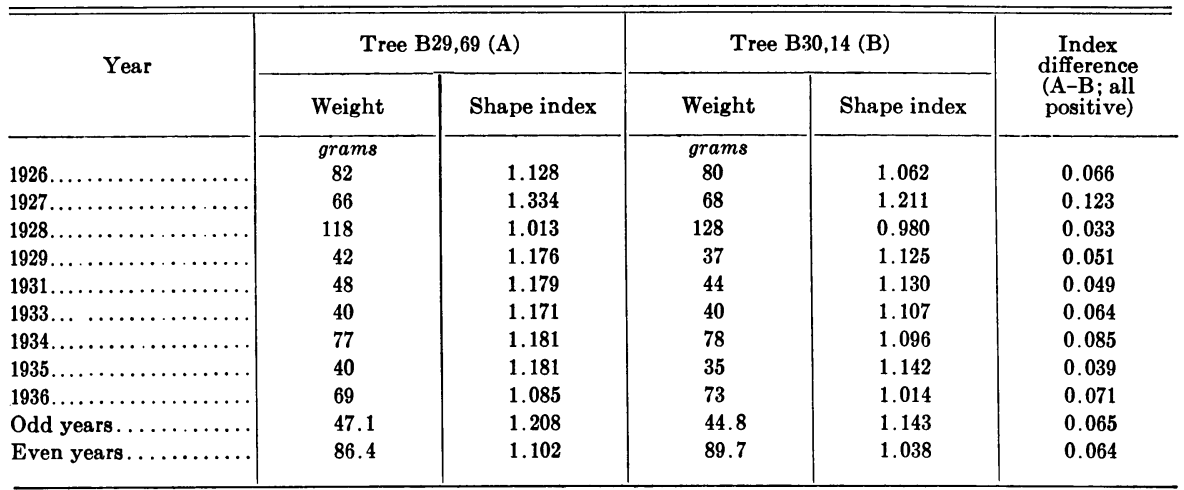

TABLE 2

PRIMARY TRIAL. MEAN SHAPE INDEX AND WEIGHT OF FRUITS FOR PAIRS OF TREES BUDDED FROM NUCFLLAR SEEDLINGS OF RT64 AND (LAST PAIR) OF RT1170

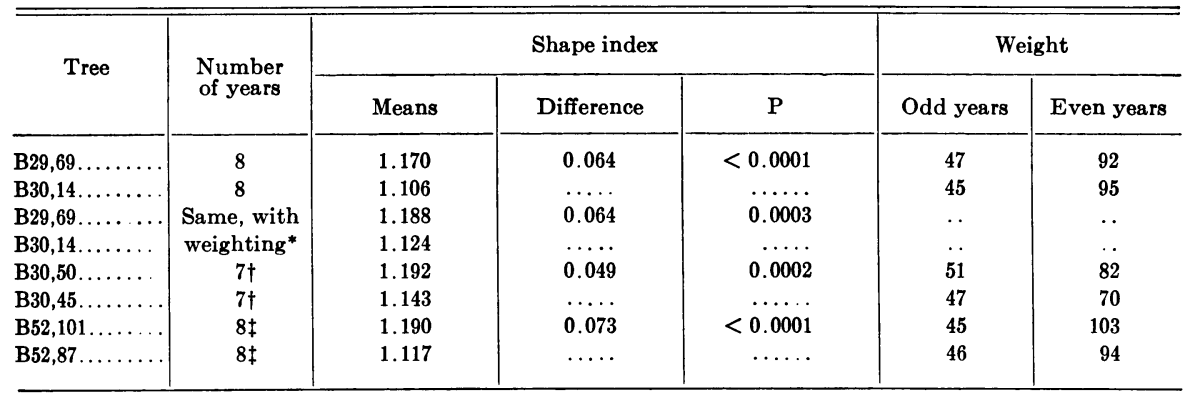

* These statistics were obtained by recalculation in which each annual sample and subsample index was weighted with the numbers of fruits represented. Degrees of freedom, 7 , for this comparison only.

$t$ The year 1928 was omitted from the records.

† For these trees, in 1934 , the scattered and clustered samples were replaced (with similar results) by samples picked, respectively, with and without some green color remaining on the rind.

within years. The general mean weights of all pairs were rather similar, also, although the second pair had considerably the lowest weights in the evennumbered years. The mean fruit-shape index was higher for the first-listed member of each pair of trees, and the differences were very highly significant in each case. The annual mean differences (not shown) within pairs were always in the same direction as the general mean differences. Recalculation for the first pair of trees, with weighting for sample size, changes the means but not their difference. 
It appears from tables 1 and 2 that the three high-index and the three low-index trees probably belonged, respectively, to at least two genetic strains. Tree B30,45, however, had a higher average index than the other low-index trees; possibly it represents a strain that is intermediate in fruit shape. The later tree characteristics, in the orchard, of the seedling from which B30,45 was budded, favor this possibility. It is believed, also, that B30,45 did not have noticeably small leaves.

Data on 16 other nucellar-line trees of the primary trial are presented in

TABLE 3

PRIMARY TRIAL. MEAN SHAPE INDEX OF FRUITS FOR TREES BUDDED FROM 16 NUCELLAR SEEDLINGS OF TREE' R'T64, RELATIVE TO "STANDARD" TREES OF TABLE 2

\begin{tabular}{|c|c|c|c|c|c|}
\hline \multirow{2}{*}{ Tree } & \multirow{2}{*}{$\begin{array}{c}\text { Number } \\
\text { of years } \\
\text { tested }^{*}\end{array}$} & \multicolumn{2}{|c|}{$\begin{array}{l}\text { Mean index as per cent } \\
\text { of standard }\end{array}$} & \multicolumn{2}{|c|}{$\begin{array}{l}\text { Significance (P) of differences } \\
\text { of annual shape indices } \dagger\end{array}$} \\
\hline & & $\begin{array}{l}\text { Of high } \\
\text { standard }\end{array}$ & $\begin{array}{l}\text { Of low } \\
\text { standard }\end{array}$ & $\begin{array}{l}\text { From high } \\
\text { standard }\end{array}$ & $\begin{array}{l}\text { From low } \\
\text { standard }\end{array}$ \\
\hline B29,61 $\ldots \ldots \ldots \ldots \ldots \ldots$ & 6 & 100.5 & 106.7 & 0.56 & $<0.0001$ \\
\hline В30,4 $\ldots \ldots \ldots \ldots \ldots \ldots$ & 7 & 99.7 & 105.8 & 0.74 & $<0.0001$ \\
\hline$B 29,21 \ldots \ldots \ldots \ldots \ldots$ & 7 & 99.4 & 105.5 & 0.42 & $<0.0001$ \\
\hline $\mathrm{B} 29,50 \ldots$ & 6 & 98.3 & 104.0 & 0.032 & $<0.0001$ \\
\hline B30,24 $\ldots \ldots \ldots \ldots \ldots \ldots$ & 7 & 98.2 & 104.2 & 0.020 & $<0.0001$ \\
\hline $\mathrm{B} 29,65 \ldots \ldots \ldots \ldots \ldots$ & 7 & 97.6 & 103.3 & 0.0022 & $<0.0001$ \\
\hline B30,10 $\ldots \ldots \ldots \ldots \ldots \ldots$ & 7 & 97.3 & 103.1 & 0.0004 & $<0.0001$ \\
\hline B29,19 $\ldots \ldots \ldots \ldots \ldots \ldots$ & 6 & 96.8 & 103.0 & 0.0001 & 0.0002 \\
\hline B30,8 $\ldots \ldots \ldots \ldots \ldots$ & 7 & 96.7 & 102.3 & $<0.0001$ & 0.0008 \\
\hline B52,70 $\ldots \ldots \ldots \ldots \ldots \ldots$ & 6 & 96.4 & 102.0 & $<0.0001$ & 0.0034 \\
\hline $\mathrm{B} 30,54 \ldots$ & 7 & 96.4 & 102.0 & $<0.0001$ & 0.0030 \\
\hline $\mathrm{B} 30,6 \ldots \ldots$ & 7 & 96.2 & 101.8 & $<0.0001$ & 0.0086 \\
\hline $\mathrm{B} 29,23 \ldots$ & 7 & 95.7 & 101.6 & $<0.0001$ & 0.023 \\
\hline B30,40 ... & $\mathbf{5}$ & 94.4 & 100.0 & $<0.0001$ & 0.96 \\
\hline $\mathrm{B} 30,18 \ldots \ldots \ldots \ldots$ & 5 & 93.7 & 100.0 & $<0.0001$ & 0.96 \\
\hline $\mathrm{B} 52,1 \ldots \ldots \ldots \ldots \ldots \ldots$ & 4 & 93.0 & 99.4 & $<0.0001$ & 0.53 \\
\hline
\end{tabular}

* Years as in table 1, always excepting 1928 and 1936 and, for the 6-year trees, 1926 also. Odd-numbered years: 5 for all but the last 3 trees, and 4 years for these. Fruit weights alternated biennially, with size of crop, much as in tables 1 and 2 , excepting 2 trees: B30,40, which had little weight alternation, and perhaps B52,1, which had no even-year record.

The $P$ values are taken from the normal-curve table, since there are 85 degrees of freedom associated with the 101 error differences from the 16 trees. For the methods of comparison with the "standard" trees, see "Statistical Procedures."

table 3 . Columns 3 and 4 give the mean fruit-shape index of each tree, expressed as percentages of "standard" means that are based on data summarized in table 2. (See "Statistical Procedures.") The percentage indices of 10 trees listed in the middle part of the table form a closely graded series, separated by slightly wider intervals from the first three trees and the last three.

Columns 5 and 6 give the $\mathrm{P}$ values of the differences of the actual mean fruit-shape index of each tree from the high and low standard means. The first three trees agreed very closely with the high standard and differed very significantly from the low standard. The next two trees differed from the high standard considerably beyond the 5 per cent level of significance, but their difference from the low standard was still extremely significant. The following seven trees differed very significantly from both standards. The next tree's difference from the low standard was significant only at the 2.3 
per cent level. The last three trees were very similar to the low standard in shape index; however, their records were less extensive than the rest, and two of them were planted in the orchard two or three years late..$^{8}$

It is possible that at least three genetic types of fruit shape may have been present among the 22 trees listed in tables 2 and 3: one type represented by the high-standard trees, one by the low-standard trees, and one or more intermediate types. Such a conclusion must be tentative because of the sensitivity of fruit shape to environmental influences. It should be empha-

TABLE 4

SECONDARY TRIAL. AREA OF TRUNK CROSS SECTION AT EIGHT-YEAR INTERVALS IN THREE PLOTS OF TREES BUDDED RESPECTIVELY FROM OLD-LINE TREE RT64, AND YOUNG-LINE TREES B29,69 AND B30,14 (SEE TABLE 1)

\begin{tabular}{|c|c|c|c|c|}
\hline Line and strain & $\begin{array}{l}\text { Number } \\
\text { of trees* }\end{array}$ & 1935 & 1943 & 1951 \\
\hline \multicolumn{5}{|c|}{ Mean cross section (sq. cm.) } \\
\hline $\begin{array}{l}\text { Old seed-parent line }(\mathrm{O}) \ldots \ldots \ldots \ldots \ldots \ldots \\
\text { Young line } 1(\mathrm{Y}-1)(\text { nucellar strain } \mathrm{A}) \ldots \ldots \\
\text { Young line } 2(\mathrm{Y}-2)(\text { nucellar strain } \mathrm{B}) \ldots \ldots\end{array}$ & $\begin{array}{l}3 \\
4 \\
4\end{array}$ & $\begin{array}{l}12.3 \\
17.0 \\
15.5\end{array}$ & $\begin{array}{l}56.3 \\
79.5 \\
81.0\end{array}$ & $\begin{array}{r}87.0 \\
116.5 \\
115.0\end{array}$ \\
\hline \multicolumn{5}{|c|}{ Difference of means, and sampling probability $(\mathrm{P})$} \\
\hline 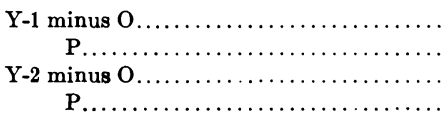 & $\begin{array}{l}\text { Plots as } \\
\text { above } \\
\text { Plots as } \\
\text { above }\end{array}$ & $\begin{array}{l}4.7 \\
0.0047 \\
3.2 \\
0.030\end{array}$ & $\begin{array}{l}23.2 \\
0.0034 \\
24.7 \\
0.0024\end{array}$ & $\begin{array}{l}29.5 \\
0.013 \\
28.0 \\
0.015\end{array}$ \\
\hline
\end{tabular}

* Plots planted in this row order. See "Materials and Experimental Methods."

sized, however, that the trees of table 2 were selected as high or low in shape index in the first year of record, and remained so. Furthermore, tree B52,70, the only intermediate tree of four measured trees in row B52, was intermediate between its high and low neighbors in every year of record.

Results in the Secondary Trial. In order to distinguish conveniently lines propagated from different nucellar seedlings, some lines have been assigned serial numbers. Such numbers do not necessarily imply genetic difference. The secondary trial, as described in "Materials and Methods," was partly composed of three orchard plots, budded respectively from three trees: B29,69 (young line 1), B30,14 (young line 2), and their seed-parent tree, RT64 (here called the old line). In tree characters these three plots are all visibly diverse.

The trees of the old-line plot have always been conspicuously smaller in top volume than those of the young lines. Since unpruned young citrus trees have a high positive correlation between top volume and trunk size, the crosssection areas of the trunks were determined in the three plots in 1935, 1943, and 1951. Table 4 shows that the mean cross section has always been larger in both young lines than in the old line, and that these differences were significant at or beyond the 3 per cent level at all determinations. The differences in cross section between the young lines have been slight and inconsistent.

\footnotetext{
${ }^{8}$ See "Materials and Methods," and the first footnote to table 3.
} 
The trees of young line 1 are uniformly more open and more spreading than those of young line 2 . Their leaves are slightly more glossy and slightly darker in color. In all these features, young line 2 is more like the old line.

Leaf measurements were taken in the three plots in 1936 and 1956. Table 5 shows that leaf-blade length and width both averaged greater in each

TABLE 5

SECONDARY TRIAL. SIZE OF LAMINA OF LEAF IN TREES OF TABLE 4

\begin{tabular}{|c|c|c|c|c|}
\hline \multirow{2}{*}{ Line (plot) } & \multicolumn{2}{|c|}{ Mean length (mm) } & \multicolumn{2}{|c|}{ Mean width (mm) } \\
\hline & 1936 & $1956^{*}$ & 1936 & $1956^{*}$ \\
\hline \multirow[t]{2}{*}{ 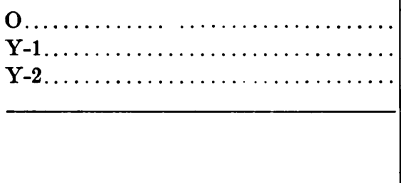 } & $\begin{array}{r}87.8 \\
105.5 \\
100.0\end{array}$ & $\begin{array}{r}90.2 \\
111.0 \\
105.7\end{array}$ & $\begin{array}{l}34.4 \\
42.5 \\
41.0\end{array}$ & $\begin{array}{l}37.1 \\
48.1 \\
44.1\end{array}$ \\
\hline & \multicolumn{2}{|c|}{$\begin{array}{l}\text { Difference in mean length, } \\
\text { and sampling probability }\end{array}$} & \multicolumn{2}{|c|}{$\begin{array}{l}\text { Difference in mean width, } \\
\text { and sampling probability }\end{array}$} \\
\hline 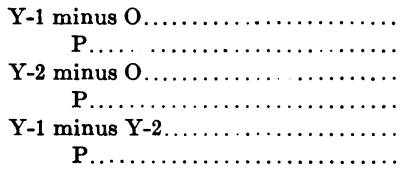 & $\begin{array}{l}17.7 \\
0.001 \\
12.3 \\
0.008 \\
5.4 \\
0.14\end{array}$ & $\begin{array}{l}20.7 \\
0.0002 \\
15.5 \\
0.002 \\
5.2 \\
0.12\end{array}$ & $\begin{array}{l}8.0 \\
0.002 \\
6.6 \\
0.008 \\
1.5 \\
0.43\end{array}$ & $\begin{array}{l}11.0 \\
0.00006 \\
7.0 \\
0.0003 \\
4.0 \\
0.006\end{array}$ \\
\hline
\end{tabular}

* All plot trees were heavily pruned, for the first time, in March, 1956. Mature leaves, all produced after this pruning, were measured in the next September. Tree G4,6 was omitted in 1956, because of poor condition from the trunk injury mentioned elsewhere (see p. 217).

\section{TABLE 6}

SECONDARY TRIAL. MEAN FRUIT-SHAPE INDICES FOR YEARS OF COMPLETE RECORD ON PLOTS OF TABLE 4

\begin{tabular}{|c|c|c|c|c|}
\hline Year & $\mathbf{O}$ & $\mathbf{Y}-1$ & $\mathrm{Y}-2$ & $\mathrm{Y}-1$ minus $\mathrm{Y}-2$ \\
\hline $1939 \ldots \ldots \ldots \ldots \ldots \ldots \ldots \ldots \ldots$ & 1.105 & 1.162 & 1.133 & +0.029 \\
\hline $1940 \ldots \ldots \ldots \ldots \ldots \ldots \ldots \ldots \ldots \ldots \ldots \ldots$ & 1.102 & 1.122 & 1.113 & +0.009 \\
\hline 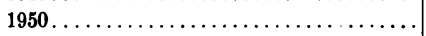 & 1.059 & 1.045 & 1.026 & +0.019 \\
\hline $1951 \ldots \ldots \ldots \ldots \ldots \ldots \ldots \ldots \ldots \ldots$ & 1.072 & 1.103 & 1.056 & +0.046 \\
\hline $1952 \ldots \ldots \ldots \ldots \ldots \ldots \ldots \ldots \ldots \ldots \ldots \ldots$ & 1.191 & 1.185 & 1.120 & +0.065 \\
\hline $1953 \ldots \ldots \ldots \ldots$ & 1.056 & 1.081 & 1.069 & +0.013 \\
\hline $1954 \ldots \ldots \ldots \ldots$ & 1.089 & 1.147 & 1.100 & +0.047 \\
\hline
\end{tabular}

young line than in the old line, and that these differences were highly to very highly significant.

The measurements also indicate somewhat larger leaf size in young line 1 than in young line 2. Although the $\mathrm{P}$ values of the difference in leaf-blade length were 0.14 and 0.12 , repeated inspections, in both the primary and the secondary trial, strongly confirm the conclusion that larger leaves are characteristic of young line 1. Petiole length was also measured in 1936. The 
mean length was least in the old line and greatest in young line 2; the difference between these two was the only statistically significant one $(\mathrm{P}=0.012)$.

All trees of the three plots produced their first fruits in the season of 1936 . Records of fruit shape and weight were made in 1939, 1940, and 1947 on all 11 plot trees. From 1949 to 1954 such records were taken in every year. Some partial records will also be reported.

Table 6 shows the annual shape indices for all plots, and the annual differences between young lines 1 and 2 . The indices were higher for young line 1 than for young line 2 in every year but one, as they invariably were

TABLE 7

SECONDARY TRIAL. MEAN DIFFERENCES IN FRUIT-SHAPE INDICES OF TREES OF TABLE 6

\begin{tabular}{l|l|l|l|l}
\hline \hline $\begin{array}{c}\text { Lines } \\
\text { compared }\end{array}$ & $1939,1940,1947$ & $1949-1954$ & \multicolumn{2}{|c}{ All nine years } \\
\cline { 2 - 4 } & Amount & P \\
\hline
\end{tabular}

All annual means given equal weight as usual

\begin{tabular}{|c|c|c|c|c|}
\hline $\begin{array}{l}\mathrm{Y}-1 \text { minus } \mathrm{Y}-2 \ldots \ldots \ldots \ldots \ldots \ldots \ldots \ldots \ldots \ldots \ldots \\
\mathrm{Y}-1 \text { minus } \mathrm{O} \ldots \ldots \ldots \ldots \ldots \ldots \ldots \ldots \ldots \ldots \ldots \ldots \\
\mathrm{Y}-2 \text { minus } \mathrm{O} \ldots \ldots \ldots \ldots \ldots \ldots \ldots \ldots \ldots \ldots\end{array}$ & $\begin{array}{l}0.028 \\
0.058 \\
0.030\end{array}$ & $\begin{array}{r}0.029 \\
0.012 \\
-0.017\end{array}$ & $\begin{array}{r}0.029 \\
0.028 \\
-0.001\end{array}$ & $\begin{array}{l}0.026 \\
0.030 \\
0.99\end{array}$ \\
\hline
\end{tabular}

Each annual mean weighted with its number of fruits*

\begin{tabular}{|c|c|c|c|c|}
\hline $\mathrm{Y}-1$ minus $\mathrm{Y}-2 \ldots \ldots \ldots \ldots \ldots \ldots \ldots$ & 0.025 & 0.029 & 0.028 & 0.008 \\
\hline $\mathrm{Y}-1$ minus $0 \ldots \ldots \ldots \ldots \ldots \ldots \ldots \ldots \ldots$ & 0.051 & 0.027 & 0.037 & 0.001 \\
\hline $\mathrm{Y}-2$ minus $0 \ldots \ldots \ldots \ldots \ldots \ldots \ldots \ldots$ & 0.026 & -0.002 & 0.009 & 0.30 \\
\hline
\end{tabular}

* As with the first pair of trees of table 2. This recalculation reduced the standard error by 22.3 per cent of its unweighted value.

in the primary trial. Table 7 , based on the data of table 6 , shows the differences in shape index between plots for the whole period, and also for the earlier and later years separately. For all nine years, the differences of young line 1 from young line 2 and from the old line were significant at or beyond the 3 per cent level, while the difference of young line 2 from the old line was not significant. Recalculation of the differences and their probabilities with weighting for annual sample size confirmed the reliability of the results obtained without weighting (table 7 ).

Four additional features are conspicuous in tables 6 and 7 , on comparison of the fruit-shape indices for the earlier and later years: (1) the generalmean shape index of the old line remained practically unchanged; $(2)$ both young lines moved nearer to the old line; (3) the difference between the young lines remained practically unchanged; but (4) it was only about half as great as in the primary trial (see table 1).

An additional comparison was made in 1943 between the two adjoining trees of young line 1 and young line 2, which in that year had exceptionally similar and uniformly distributed crops. Shape indices were determined from the north and south halves of the trees, separately. Table 8 shows that the tree of young line 1 had the higher index in both compari- 
sons.The mean difference for the whole tree $(0.088)$ considerably exceeded the highest in tables 6 and 7, and was very highly significant. This difference was even greater than the general mean difference of the bud-parent trees in the primary trial.

The results of the secondary trial in the main, therefore, agree with those of the primary trial in indicating that young line 1 typically has flatter fruit than young line 2, although both seem to be changing toward a lower index.

Two trees have been strikingly exceptional in shape index, in the youngline plots. Tree G3,10 was lowest in general mean in its high-index plot;

TABLE 8

SECONDARY TRIAL. MEAN SHAPE INDEX* AND WEIGHT OF FRUITS IN TWO ADJACENT TREES OF YOUNG LINES 1 AND 2 WITH VERY SIMILAR AND UNIFORM CROPS (1943)

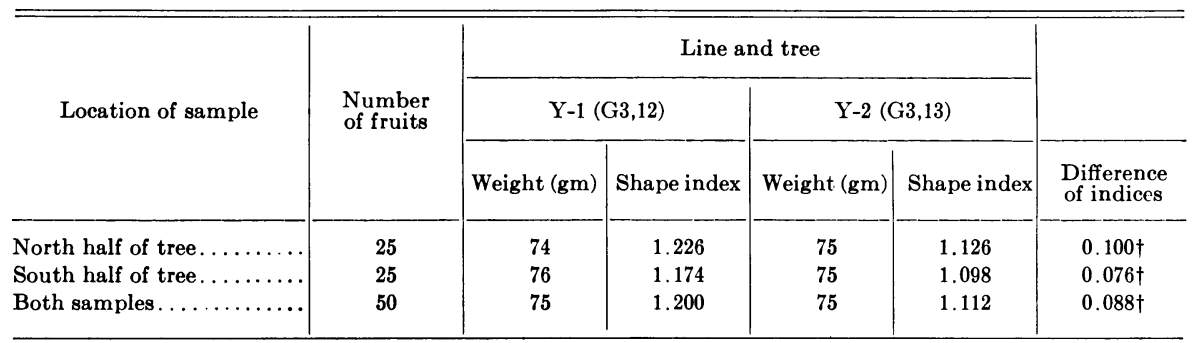
(1932).

* Obtained from individual-fruit measurements. This is the $\mathrm{D} / \mathrm{H}$ index (diameter/full-height) of Tanaka

$\dagger P$ is less than 0.0008 . Standard error is based on the pooled variation of the individual-fruit indices.

and G3,15 was highest in its low-index plot, actually higher than G3,10. In annual mean index, these trees were similarly exceptional in their plots throughout the nine years covered by table 6 , each differing in the direction stated in 24 comparisons out of 27 with the other three trees of its plot. The general mean yields of these trees from 1939 to 1955 were the lowest in the respective plots. However, in 1936, the year of first crop, these trees had relatively heavy yields among the 11 plot trees, and in that year, in 100-fruit samples, tree 10 had a higher shape index than tree 15 , by 0.021 .

Several other characters, of special horticultural interest, have been studied in the three plots of the secondary trial. Some of the contrasts between young line 1 and the old line were briefly indicated in a general report on effects of nucellar embryony in citrus (Cameron and Soost, 1952). A more thorough comparison, including data on young line 2 , is presented below.

In the second and third years of fruit production, 1937 and 1938, the yields were light, and the total per-tree yields of the plots differed little (table 9, section A). In the six years of record from 1939 to 1946, the annual mean yields of the young lines, without exception, exceeded those of the old line; the six-year excess of young line 1 was 84 per cent, and that of young line 2 was 72 per cent. The actual differences were significant near or beyond the 2 per cent level, while the difference between young line 1 and young line 2 was not statistically significant (table 9 , section $\mathrm{C}$ ).

In the nine years from 1947 to 1955 (table 9, section A), young line 1 exceeded the old line by 71 per cent, about one-sixth less than before; young 
line 2, however, exceeded the old line by only 36 per cent, one-half less than before; these differences from the old line were significant beyond the 0.5 per cent and 2 per cent levels, respectively. In sharp contrast to the earlier results, the difference between the two young lines was significant at the 0.5 per cent level.

TABLE 9

SECONDARY TRIAL. YIELD OF FRUIT AND EARLINESS OF FRUIT COLORING IN THE OLD-LINE AND YOUNG-LINE PLOTS OF TABLE 4

\begin{tabular}{|c|c|c|c|c|c|c|c|c|c|c|}
\hline \multirow[t]{2}{*}{ Line } & \multicolumn{10}{|c|}{ A. Mean yield in pounds per tree } \\
\hline & 1937 & 1938 & 1939 & 1940 & 1941 & 1942 & $1943^{*}$ & $1946^{*}$ & $\ldots$ & $1937-46$ \\
\hline O... & 19 & 23 & 58 & 79 & 70 & 92 & 22 & 44 & $\ldots$ & 51 \\
\hline $\mathrm{Y}-1 \ldots \ldots \ldots \ldots$ & 33 & 9 & 140 & 96 & 176 & 120 & 81 & 58 & $\cdots$ & 89 \\
\hline \multirow[t]{2}{*}{$\mathrm{Y}-2 \ldots \ldots \ldots \ldots$} & 33 & 11 & 126 & 98 & 154 & 116 & 76 & 57 & . . & 84 \\
\hline & 1947 & 1948 & 1949 & 1950 & 1951 & 1952 & 1953 & 1954 & 1955 & $1947-55$ \\
\hline $0 \ldots \ldots \ldots \ldots$ & 57 & 65 & 69 & 104 & 82 & 78 & 86 & 78 & 101 & 80 \\
\hline $\mathrm{Y}-1 \ldots \ldots \ldots$ & 135 & 184 & 60 & 147 & 130 & 170 & 127 & 86 & 198 & 137 \\
\hline$Y-2 \ldots \ldots \ldots \ldots$ & 114 & 138 & 74 & 133 & 84 & 113 & 85 & 77 & 163 & 109 \\
\hline
\end{tabular}

B. Mean percentage of well-colored fruit on date of harvest $\dagger$

\begin{tabular}{|c|c|c|c|c|c|c|c|c|c|c|}
\hline & 1947 & 1948 & 1949 & 1950 & 1951 & 1952 & 1953 & 1954 & 1955 & $1947-55$ \\
\hline $0 \ldots$ & 76 & 29 & 78 & 68 & 56 & 79 & $\ldots$ & .. & 32 & 60 \\
\hline Y-1.. & 100 & 89 & 82 & 96 & 85 & 99 & $\ldots$ & $\ldots$ & 100 & 93 \\
\hline $\mathrm{Y}-2$. & 99 & 79 & 84 & 74 & 54 & 89 & $\ldots$ & $\ldots$ & 100 & 83 \\
\hline
\end{tabular}

C. Significance of mean difference of annual means $\ddagger$

\begin{tabular}{|c|c|c|c|c|c|c|}
\hline \multirow[t]{2}{*}{ Comparison } & \multicolumn{2}{|c|}{ Yield 1939-43, 1946} & \multicolumn{2}{|c|}{ Yield 1947-55 } & \multicolumn{2}{|c|}{ Coloring 1947-55 } \\
\hline & Mean diff. & $\mathrm{P}$ & Mean diff. & $\mathbf{P}$ & Mean diff. & $\mathbf{P}$ \\
\hline $\begin{array}{l}\mathrm{Y}-1 \text { minus } \mathrm{O} \ldots \ldots \ldots \\
\mathrm{Y}-2 \text { minus } \mathrm{O} \ldots \ldots \ldots \ldots \\
\mathrm{Y}-1 \text { minus } \mathrm{Y}-2 \ldots \ldots \ldots \ldots\end{array}$ & $\begin{array}{r}51 \\
44 \\
7\end{array}$ & $\begin{array}{l}0.021 \\
0.015 \\
0.10\end{array}$ & $\begin{array}{l}57 \\
29 \\
28\end{array}$ & $\begin{array}{l}0.004 \\
0.018 \\
0.005\end{array}$ & $\begin{array}{l}33.3 \\
23.0 \\
10.3\end{array}$ & $\begin{array}{l}0.0023 \\
0.042 \\
0.15\end{array}$ \\
\hline
\end{tabular}

* Doubtless the yields were reduced in 1943 and 1946 by lack of nitrogen fertilization during the war.

† Orange color, 70 per cent or more. See "Materials and Experimental Methods." correlation of means (all positive) are as follows: for yield (15 years): $\mathrm{Y}-1$ and $\mathrm{Y}-2,0.90 ; \mathrm{Y}-1$ and $0,0.45 ; \mathrm{Y}-2$ and $\mathrm{O}$. 0.45 . For coloring (7 years): $\mathrm{Y}-1$ and $\mathrm{Y}-2,0.67 ; \mathrm{Y}-1$ and $0,0.01 ; \mathrm{Y}-2$ and $0,0.04$. The only significant value of $r$ is the first: for its difference from zero, $P$ is less than 0.00006 .

The mean yields of the young-line plots (table 9, section A) alternated biennially through most of this trial, but very much less than those of the trees in the primary trial. Almost invariably, all the trees in each plot alternated in synchronism, although they sometimes differed greatly in amount of change. Corresponding to the slight alternation, the annual mean fruit weights were definitely intermediate between those of the "bearing" years and those of the "off" years of the primary trial. The old-line yields showed much less biennial alternation, and consequently were much less closely correlated with the young-line yields than the latter were with each other (table 9 , section $\mathrm{C}$, footnote). 
The general mean weight per fruit, calculated from samples, was nearly identical in the old line and young line 1, but was a little lower in young line 2. When the mean weight was calculated on the basis of total crop weight and number of fruits, it was only slightly reduced because of smaller fruits in heavier crops; the reduction was equal with the old line and young line 1 and slightly greater with young line 2 . Young line 1 , at least, seems to be at no disadvantage in long-run mean fruit size, in comparison with the old line. The young lines have somewhat greater size variation within the tree, which evidently is related to less uniform distribution of the fruits.

Time of coloring of the fruit has usually been considerably earlier in the young lines than in the old line. In table 9 , section $\mathrm{B}$, the coloring data are presented for each plot of trees for the same crops as the yield data. In most years, on the date chosen for record, the fruit of the young lines was markedly better colored than that of the old line. The mean differences

TABLE 10

SECONDARY TRIAL. JUICE CHARACTERS OF FRUIT OF THE OLD-LINE AND YOUNG-LINE PLOTS OF TABLE 4, OVER AN EIGHT-YEAR PERIOD

\begin{tabular}{l|c||c|c|c|c|c|c|c|c|c}
\hline \hline & Line & 1947 & 1948 & 1949 & 1950 & 1951 & 1952 & 1953 & 1954 & $\begin{array}{c}\text { Mean } \\
\text { for all } \\
\text { years }\end{array}$ \\
\hline Percentage & $\mathrm{O}$ & 50.0 & 48.9 & 39.9 & 45.2 & 44.4 & 40.4 & 43.4 & 48.2 & 45.1 \\
of juice & $\mathrm{Y}-1$ & 53.8 & 49.0 & 40.2 & 41.7 & 46.1 & 40.1 & 41.0 & 48.0 & 45.0 \\
& $\mathrm{Y}-2$ & 52.3 & 51.9 & 39.8 & 41.8 & 45.8 & 38.4 & 44.6 & 45.9 & 45.1 \\
\hline Percentage of & $\mathrm{O}$ & 12.5 & 11.4 & 12.6 & 11.9 & 11.8 & 11.8 & 11.8 & 12.8 & $12.1^{*}$ \\
soluble solids & $\mathrm{Y}-1$ & 13.6 & 12.3 & 14.0 & 13.4 & 12.9 & 13.8 & 13.0 & 14.5 & $13.4^{*}$ \\
& $\mathrm{Y}-2$ & 14.1 & 12.6 & 14.0 & 12.6 & 12.4 & 13.3 & 12.8 & 14.1 & $13.2^{*}$ \\
\hline Percentage & $\mathrm{O}$ & 1.32 & 1.11 & 1.56 & 1.27 & 1.08 & 1.35 & 1.21 & 1.45 & 1.29 \\
of acid & $\mathrm{Y}-1$ & 1.28 & 1.09 & 1.68 & 1.31 & 1.10 & 1.40 & 1.24 & 1.62 & 1.34 \\
& $\mathrm{Y}-2$ & 1.19 & 1.09 & 1.55 & 1.24 & 1.09 & 1.37 & 1.16 & 1.62 & 1.29 \\
\hline Solids/acid & $\mathrm{O}$ & 9.5 & 10.3 & 8.1 & 9.4 & 10.9 & 8.7 & 9.8 & 8.8 & 9.4 \\
ratio & $\mathrm{Y}-1$ & 10.6 & 11.3 & 8.3 & 10.2 & 11.7 & 9.9 & 10.5 & 9.0 & 10.2 \\
& $\mathrm{Y}-2$ & 11.9 & 11.6 & 9.0 & 10.2 & 11.4 & 9.7 & 11.0 & 8.7 & 10.4 \\
\hline
\end{tabular}

* The values of $\mathrm{P}$ for the differences: $\mathrm{Y}-1$ and $\mathrm{Y}-2$ minus $\mathrm{O}$, each less than $0.0001 ; \mathrm{Y}-1$ minus $\mathrm{Y}-2,0.23$.

of young line 1 and young line 2 from the old line are highly and moderately significant, respectively (table 9 , section $\mathrm{C}$ ). The difference between the two young lines is not significant. The method employed in separating the color classes tends to understate the differences. Thus when most of the fruits were well colored, the total amount of rind still green in both classes was very small compared with the amount still green when most of the fruits were poorly colored. The difference between young line 1 and young line 2 was definitely noticeable even though it was not statistically significant as measured.

It may be seen that there is considerable relationship between high yield per tree and percentage of fruits well colored at time of record. In years of heavy crop, fruit of young line 1 approached 100 per cent well colored when the old-line fruit was still poorly colored. In 1949, however, when young line 1 had an unusually light crop, coloring was late and little differ- 
ent from that in the parent line. In light-crop years young line 2 was likewise slow to color, but in heavy-crop years it was not as consistent in coloring as young line 1. In only two of the five heavy-crop years which were rated for coloring was young line 2 colored as well as young line 1 . It is probably important that its "heavy" crops were not as great in pounds per tree as those of line 1 in the same years.

As has been stated, the top volumes of the trees of both young-line plots are much greater than those of the old line. This means that yield per unit volume of top is often no greater in the young lines than in the old line. The earlier coloring, especially in young line 1, occurs despite approximate equality in relative yield. Only in a year such as 1949, when yield per unit volume in the young lines was much less than that in the old line, was the time of coloring about equal.

Table 10 shows the mean percentages of juice, soluble solids, and acid, and the solids/acid ratios of fruit of the three lines from 1947 through

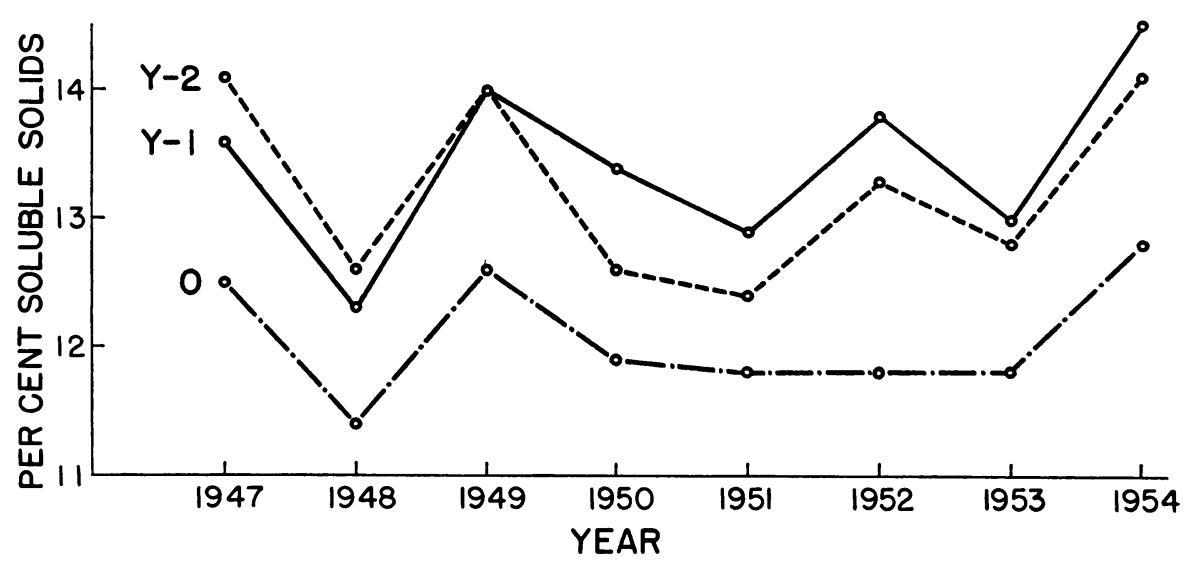

Fig. 2. Per cents of soluble solids in the fruit of the secondary-plot trees of the old-line Satsuma (0) and young lines Y-1 and Y-2, in eight consecutive years.

1954. The percentages of juice have not shown consistent differences among the lines, and the means for the whole period are almost identical.

A marked difference in percentage of soluble solids between the old line and the two young lines has been characteristic. The data from table 10 are shown graphically in figure 2. Soluble solids were higher in both young lines than in the old line, in each year. The differences of the general means between the old line and each young line are very highly significant (table 10 , footnote), but they are not significant between the two young lines. Considered in relation to table 9 , it is evident that these differences do not depend upon yield or time of fruit coloring.

In the seasons of 1953 and 1954, soluble solids were measured on each plot tree at four sampling dates. The data are shown in figures 4 and 5 . Solids in the young lines were well above those of the old line throughout both seasons. As with the data of table 10, the differences from the old line were statistically highly significant, while the differences between the young lines were not significant. There was no tendency for the old line 


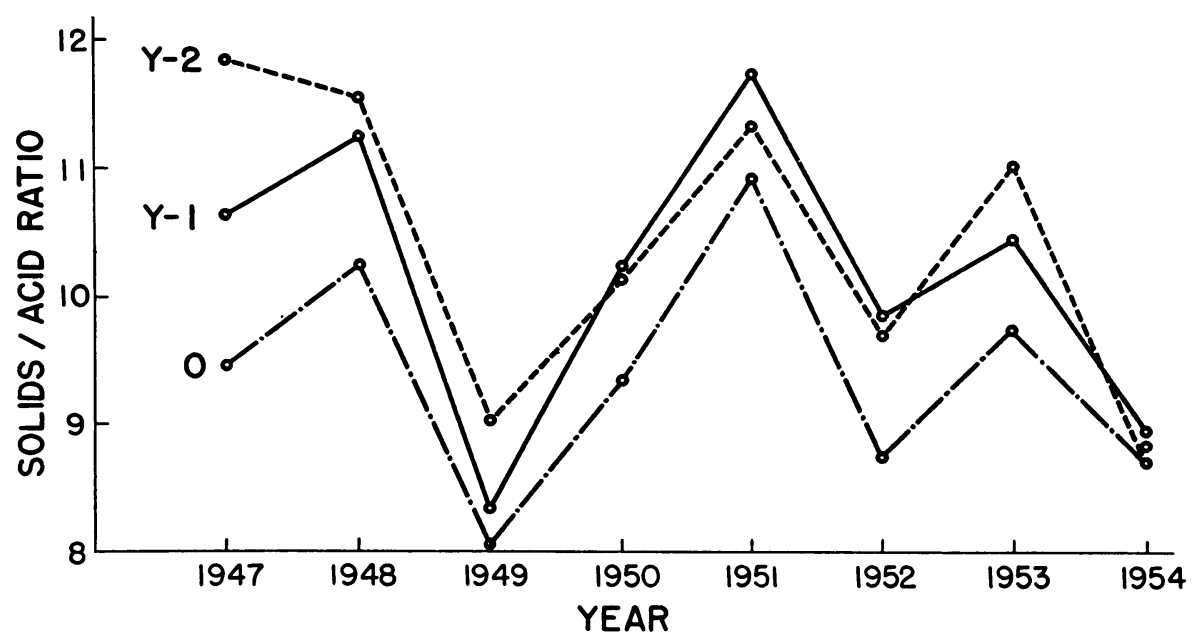

Fig. 3. Solids/acid ratios of the fruit of the Satsuma plot trees of figure 2, over the same period of years.

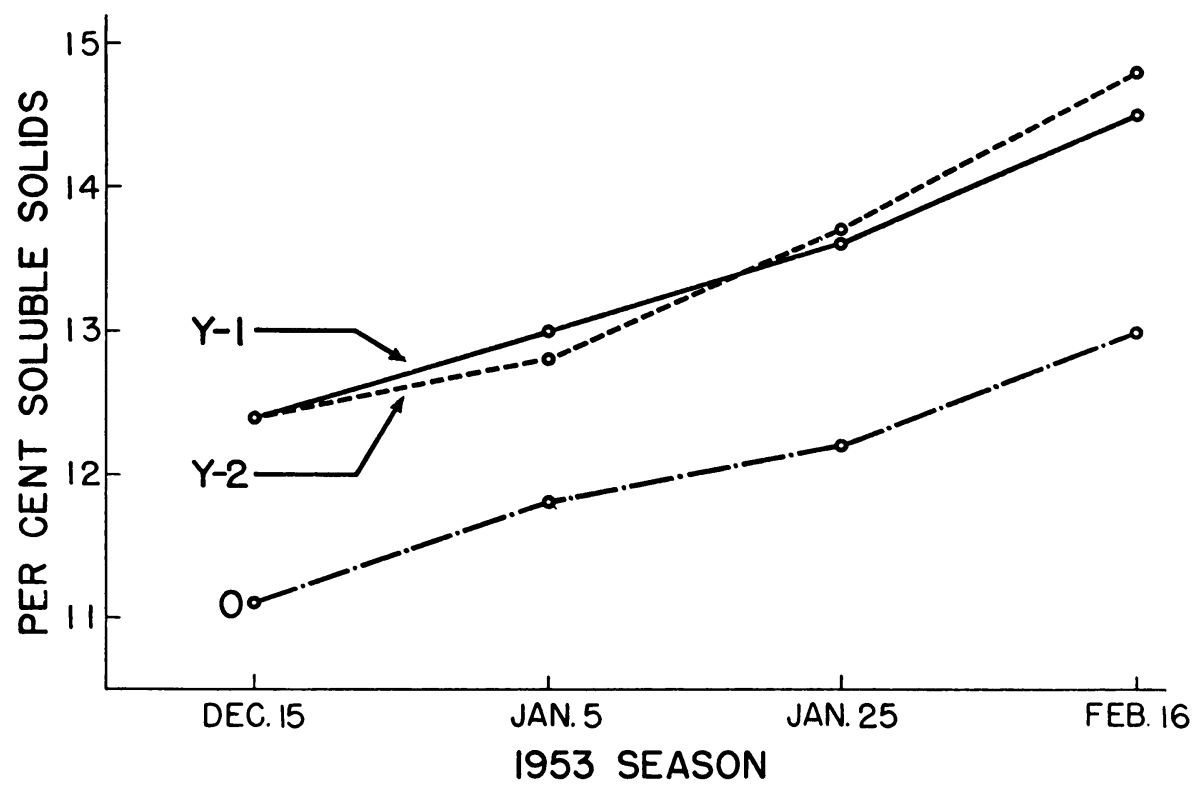

Fig. 4. Per cents of soluble solids at four sampling dates in 1953, in the Satsuma plot trees of figure 2.

to overtake the young lines in solids content as the season progressed, even though the fruit rinds became well colored in all samples.

One tree of young line 1 has been persistently lower in solids than its sisters. Tree G3,9, although not as low as the old-line average, has been intermediate in each year's tests. 
Further evidence of the higher solids among the young lines is available from a small orchard planting made in 1949, on trifoliate-orange rootstock. Fruits from trees budded from the old line, from the "intermediate" tree of young line 1 just discussed, and from an additional young line (line 4) which has shown characteristics very similar to line 1 and seems to be genetically identical with it, were analyzed in 1954 and 1955. In both

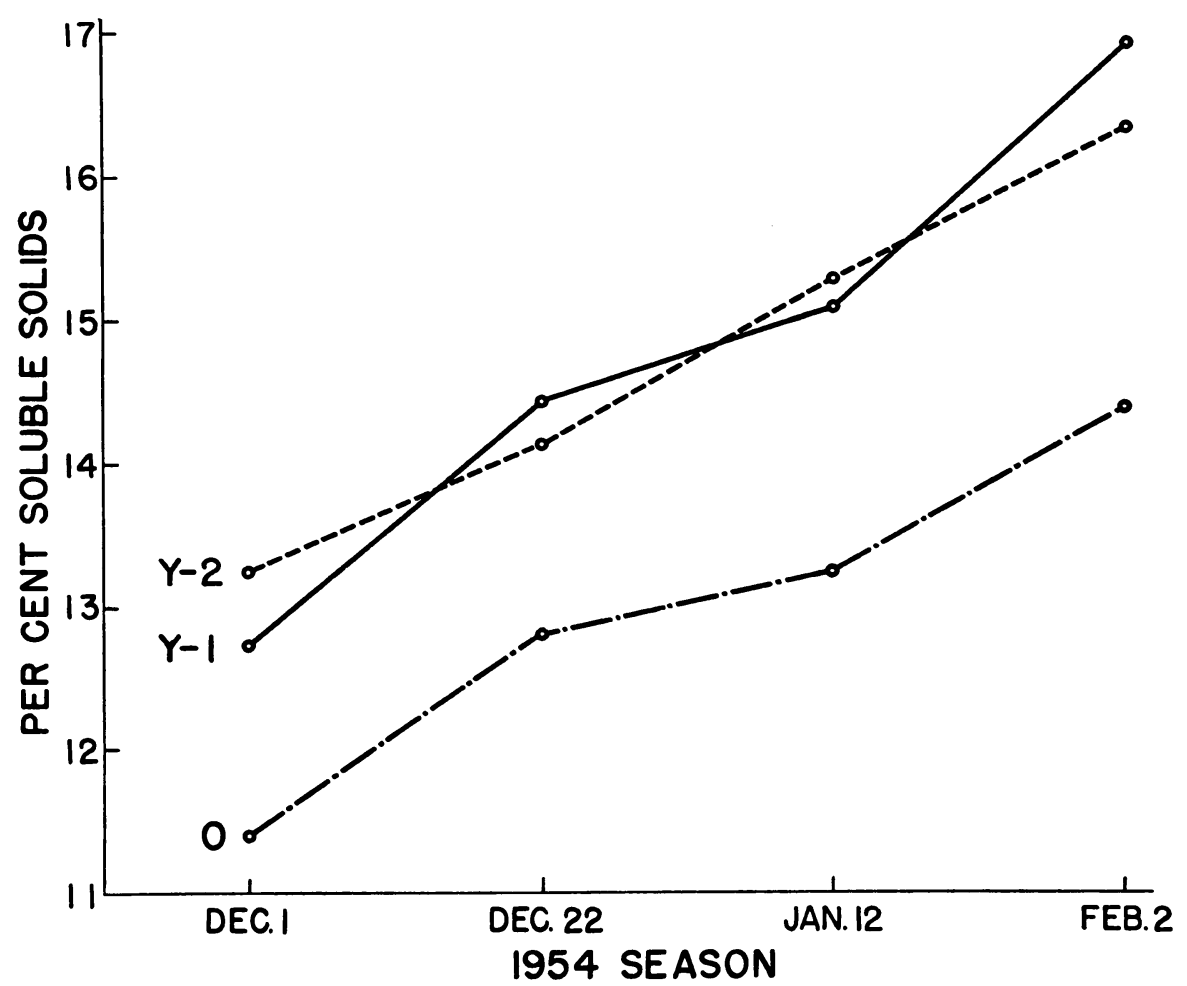

Fig. 5. Per cents of soluble solids at four sampling dates in 1954 , in the Satsuma plot trees of figures $2-4$.

seasons the old line was lowest in soluble solids, the line representing the "intermediate" tree was intermediate, and the trees considered similar to young line 1 were highest.

Percentage of acid (table 10) has been fairly similar, within years, in the fruit of the three lines. No consistent differences related to the differences in solids have been found, although there is a tendency for higher acid to accompany higher total solids. One tree of young line $2(\mathrm{G} 4,6)$ has been lower in acid than its sisters in nearly all tests, but an injury which partially girdled the trunk and crowding by an adjacent lemon tree may have influenced its behavior. In the two years of especially light crops (1949 and 1954) acid was much higher than average in all three lines.

As a result of having higher solids without accompanying higher acid, the young lines usually have substantially higher solids/acid ratios than 
the old line (figure 3 ). The only exception is 1954 , one of the two years of generally light crops just mentioned.

It has recently been shown in Texas and California (Olson and McDonald, 1954; Wallace et al., 1956) that some lines of Satsuma are carrying the virus of tristeza disease. It was therefore important to determine whether any of the characteristic differences among the lines discussed in this paper could be ascribed to tristeza. Inoculation tests on Mexican-lime seedlings were made in 1955 by Robert Drake, of the Department of Plant Pathology, from the old seed-parent tree, the budded trees of the secondary plots, and several other related trees. The results were negative in all cases. Thus tristeza is evidently not a complicating factor in these studies. Leaf examinations for the psorosis virus, made some years ago by H. S. Fawcett on all trees of the secondary-trial plots, were also negative.

Strain Designation. Although the possibility of undetected viruses cannot be eliminated, it seems certain from the secondary-trial results that young line 1 does differ genetically from young line 2. Therefore these two types have been designated, respectively, as strains $A$ and $B$. In addition to these strains, a third clearly distinct type, strain C, has been identified. This type originated as a seedling from the same small seed-parent branch (bagged for cross pollination) as produced young line 1 (strain A). Three budded trees of strain $\mathrm{C}$ have been studied. One prominent characteristic of this strain is the late ripening of the fruit, which colors about a month after strains A and B. The fruit is considerably firmer than that of the latter strains, mainly because of less axis hollowness and moderately thicker rind. Many observations on firmness and rind thickness were confirmed by records on 40-fruit samples in two seasons, in comparison with neighboring Satsumas, including strain A. Strain C is more erect than strains A and B in tree habit, and its leaves are considerably smaller and more numerous.

Seedling Trees. In the fruit seasons of 1947 and 1951, 10 of the original unbudded nucellar-seedling trees, which had been maintained in two rows preceding the secondary-trial plots, were classified for growth habit. This classification was made independently of the fruit-shape records of their budded offspring. Comparison with the budded trees of strains A and B in the plots was made difficult by some general differences, the seedling trees being larger and less compact.

All three of the seedlings from which the high-index trees of table 2 had been budded were present, and all had the more open and large-leaved growth habit of nucellar strain A. Two other seedlings whose budded offspring (B30,4 and B29,50) had high fruit-shape indices (table 3) were also classed as strain A. Two seedlings whose offspring (B30,10 and B52,70) had intermediate fruit-shape indices (table 3) were not strain B, but were classed as questionably strain A. Of the low-index trees of table 2, only the seedling parent of B30,45 was present, and this was classed as questionably strain A. Two other seedlings were classed as strain B; the budded offspring of these (B29,65 and B30,8) had intermediate fruit-shape indices (table 3 ). (The seedlings which gave the other trees of table 3 were not present.) Thus, of the seedlings present, all trees positively classified as strain A had given budded progeny with high fruit-shape indices, while 
those classified either as strain B or questionably as strain A, had given either intermediate or low indices.

The two orchard seedlings classified as strain B and three of the five classified as strain A came from seeds produced on separate scattered small branches that were bagged for cross pollination on tree RT64 in 1915. Another such branch gave both the seedling ancestral to young line 2 (strain B) and the seedling giving B30,10 (questionably A). Another such branch gave the seedling of questionable A type that was the bud parent of B30,45. It is therefore demonstrated that both strain A and strain B occurred repeatedly among the nucellar seedlings of tree RT64, and also that the seeds concerned came from various locations on that parent tree. Since the seedling of strain C came from the same small branch as a seedling of strain A, as has been noted, it is evident that in one or more instances embryos of two strains came from one small branch.

\section{DISCUSSION}

Nucellar Origin of the Experimental Trees. Nucellar origin of citrus seedlings is ordinarily indicated by close resemblance to the seed parent and, after cross pollination, by absence of pollen-parent characters. Almost invariably, gametic seedlings, even from selfing, are readily distinguished from nucellar ones by fruit characters (Frost, 1926, 1952). With our Satsumas, the only possibly questionable type is strain $\mathrm{C}$, which is rather unlike the seed parent. The pollen parent of the attempted cross was Valencia orange, but strain $\mathrm{C}$ shows no orange characters. Occasionally a hybrid between Citrus species is remarkably similar to one parent, female or male. Presumably this occurrence is more probable with triploid hybrids, which receive two thirds of their chromosomes from their female parent. Strain $\mathrm{C}$, however, is not triploid; its chromosome number is $2 \mathrm{n}=18$, with usual formation of nine bivalents in the first meiotic division.

Origin of the strain-C seedling by self-fertilization is also unlikely. First, both artificial pollen cultures and pollination trials have indicated high sterility, probably not always complete, of Satsuma pollen (Tanaka, 1932, p. 40, 582; Frost, pp. 790, 810, in Webber and Batchelor, 1943). Second, the strain-C embryo originated after guarded cross pollination of an emasculated flower. Third, Satsuma flowers bagged without emasculation in the same experiments, produced numerous fruits but no seeds.

Origin and Stability of Strain Differences. The evidence is inadequate to indicate the relative frequency of occurrence of strains $\mathrm{A}$ and $\mathrm{B}$ among the several hundred nucellar seedlings originally obtained from the two parent Satsuma trees. Strain C, however, occurred only once. The data suggest that strains A and B were both represented in shoots of tree RT64 prior to the flowering season of 1915 .

Young-line trees of strain B, in the secondary trial, are considerably more like the old line in tree habit and fruit shape, than are trees of strain A. But in tree size and per cent of soluble solids strain B is similar to strain A and decidedly unlike the old line. In yield, strain B is at present intermediate between strain $\mathrm{A}$ and the old line. It may be that the budwood which produced the old-line plot trees, and the seeds which produced 
strain B, both came from strain-B portions of the parent tree, while the seeds which produced strain A came from strain-A portions of the parent. Nucellar embryony commonly results in larger trees and higher yields, as found in both these nucellar strains, but earlier coloring and higher soluble solids are not typical of nucellar lines of other citrus varieties. It is possible, but unproved, that elimination of unidentified virus infection has caused these two differences in our Satsumas.

It is difficult to ascribe all the changed characteristics of the nucellar lines to the elimination of viruses in embryo formation. This postulation would imply that young line 2 either retained or early reacquired a part of certain seed-parent viruses that are still absent from young line 1 . This possibility is opposed by the very similar tree size of the two young-line plots, by the fact that strain $\mathrm{C}$ can hardly be accounted for in this way, and by the origin in Japan of numerous recognizable strains of Satsuma from limb sports (Tanaka, 1932).

The relation of strains $\mathrm{A}, \mathrm{B}$, and $\mathrm{C}$ to the Japanese "varieties" is uncertain. Our old line is considered to be the variety Owari, and Tanaka recognizes the occurrence of minor strain variations within this variety. The fruit of strain $\mathrm{C}$ resembles that of the Ikeda, as described by Tanaka, in its thick rind, solidity, and late ripening, but our trees are not dwarfed and spreading like the Ikeda trees. Fruit shape can hardly be compared, since shape indices indicate that Satsuma fruit in Japan is usually much flatter than in California.

The valuable Wase Satsuma has sometimes reverted to its bud-variation parent, the Owari, in Japan. It is possible that this instability has been due to a chimeral structure that included the Owari type. Our nucellar Satsuma strains should not be initially chimeral in structure, since each nucellar embryo apparently arises from a single cell.

We have found, in two nucellar strains of sweet orange, a highly variable type of instability in pollen and navel formation. These strains, called Rufert and Trovita, are essentially non-navel, pollen-bearing forms, each of which has been produced by several seeds of its respective parent tree (Frost, pp. 839, 900 in Webber and Batchelor, 1943). The lines propagated from certain seedlings have fruits with no navel, or only traces of navel. Those propagated from other seedlings, however, are unstable: trees in the first and second budded generations have various degrees of pollen sterility and accompanying increased navel development and reduced seed formation, often highly variable within a tree. The seed parent of the Rufert is known, and is a navel type called Ruvel, strictly without pollen; it seems otherwise identical with the nucellar Rufert. Our Satsuma strains, including the exceptional trees within the young-line plots, suggest genetic instability, but not with such phenotypically conspicuous effects as the variations in pollen and navel described above.

Effects of Environment and Age of Line on Fruit Shape. The principal differences in fruit shape reported here can hardly have been due to tree position in the row, in relation to furrow irrigation. (The water flowed throughout each row from above tree number 1.) Among the six trees of table 2, flatter shape does accompany higher tree number within the row, 
but in table 3 fruit shape seems to be distributed without relation to row position. Growth, as evidenced by area of trunk cross section in 1925, in the sixteen trees of this study which were planted in 1920, was practically identical between the upper and lower halves of the rows. In the secondary plots of table 6 the trees of young line 1, with flatter fruit than those of young line 2 , were mainly nearer the irrigation source, but the trees of the old line, in the same row, were nearest of all.

Between the two periods of the secondary trial, the fruit-shape index of both young lines decreased, approaching the consistently deep fruit of the old line. This behavior is suggestive of change in a juvenile condition originally favoring flatter fruit, similar to the decrease in tendency to thorniness which occurs as young seedling lines grow older. In the secondary trial, the annual differences in fruit-shape index between young line 1 and young line 2 were also less than in the primary trial. This strain difference, however, does not seem to be disappearing. It was about the same in 1949-1954 as in 1939-1947 ; and in 1943, under especially uniform conditions, it was as great as in the primary trial. Its lower mean value in the secondary trial is probably related to the lower biennial alternation in yield, with consequent decreased uniformity of fruit shape within years.

Horticultural Value of the Nucellar Strains. Among the Satsuma lines described here, nucellar strain A has been very superior to strains B and $\mathrm{C}$, and to the old-line trees, in overall horticultural promise. Its fairly regular heavy crops and relatively early coloring, together with soluble solids which are higher than in the old line, should make it useful in extension of the presently very small acreage of Satsumas in California. Adequate comparisons with Satsumas from other sources have not been available, however. Strain A has been established in Kern County, in the early Washington Navel orange district, for several years. This is an area outside the tristeza-virus quarantine. In a planting of specimen trees there, it has seemed the most promising of several mandarin types.

\section{SUMMARY}

Long-time studies of nucellar-seedling lines derived mainly from a single seed-parent Satsuma tree indicate that both genetic change and nucellar embryony are responsible for observed differences. Two nucellar lines each show larger tree and leaf size, greater yields, and greater interannual variation in yield, than the parent line. These differences can be ascribed to nucellar embryony. Fruit coloring is earlier in these nucellar lines in years of good crop, and is at least equal to that of the old line in low-crop years. The per cent of soluble solids has been consistently higher in the fruit of both the nucellar lines throughout the ripening season. Other fruit characters, excepting shape, have not shown any notable differences between the parental and two nucellar lines.

Trees of line 1 are more open in branching habit than those of line 2 . Fruit shape has been flatter in line 1 than in line 2, and leaf size is apparently larger. Although clearly of nucellar origin, the two lines are thus genetically distinct and have been designated as strains A and B. Other nucellar lines derived from other seedlings of the same parent, show tree 
and fruit-shape characters which indicate that some of them belong to strain $A$ and some to strain B, while some are perhaps distinct from both these strains. A third genetic strain (C), apparently nucellar, which is much later in time of maturity of fruit, has also been definitely identified. Strain A exhibits the best overall combination of horticultural characters. The old line and all of the nucellar lines examined for virus disease have evidently been free from tristeza and psorosis.

\section{LITERATURE CITED}

Batchelor, L. D., and J. W. CAMERoN

1949. Nucellar seedling strains of citrus. Florida State Hort. Soc. Proc. 62:55-65.

CAMeron, J. W., and R. K. Soost

1952. Size, yield, and fruit characters of orchard trees of citrus propagated from young nucellar-seedling lines and parental old lines. Amer. Soc. Hort. Sci. Proc. 60:25564.

Frost, H. B.

1926. Polyembryony, heterozygosis and chimeras in citrus. Hilgardia 1(16):365-402.

1938. Nucellar embryony and juvenile characters in clonal varieties of citrus. Jour. Hered. 29:423-32.

1952. Characteristics in the nursery of citrus budlings of young nucellar-seedling lines and parental old lines. Amer. Soc. Hort. Sci. Proc. 60:247-54.

Hodgson, R. W., and S. H. CAMERoN

1938. Effects of reproduction by nucellar embryony on clonal characteristies in citrus. Jour. Hered. 29:417-19.

Olson, E. O., and J. R. McDonald

1954. Tristeza in Satsuma varieties in Texas. Plant Disease Reporter 38:439-41.

"STUDENT."

1925. New tables for testing the significance of observations. In "Student's" Collected Papers, pp. 115-20. University Press, Cambridge, England.

SWINGLE, W. T.

1932. Recapitulation of seedling characters by nucellar buds developing in the embryo sac of Citrus. Sixth Internatl. Cong. Genet. Proc. 2:196-97.

SWINGLE, W. T., and T. R. RoBInson

1931. The Silverhill: a promising and apparently hardy strain of Satsuma orange. Flor. ida State Hort. Soc. Proc. $44: 201-02$.

Tanaka, Tyozaburo

1932. A monograph of the Satsuma orange, with special reference to the occurrence of new varieties through bud variation. Taihoku Imp. Univ., Faculty Sci. and Agr. Mem. 4:1-626. 53 pls.

W Allace, J. M., P. C. J. Oberholzer, and J. D. J. HoFmeyer

1956. Distribution of viruses of tristeza and other diseases of citrus in propagative material. Plant Disease Reporter 40:3-10.

WEBBER, H. J., and L. D. BATCHELOR (Eds.)

1943. The citrus industry, Vol. I. History, botany, and breeding. $x x+1028 p$. University of California Press, Berkeley and Los Angeles. (In text reference to this volume, author and page precede editors and date.) 
The journal Hilgardia is published at irregular intervals, in volumes of about 600 pages. The number of issues per volume varies.

Subscriptions are not sold. The periodical is sent as published only to libraries, or to institutions in foreign countries having publications to offer in exchange.

You may obtain a single copy of any issue free, as long as the supply lasts; please request by volume and issue number from:

Agricultural Publications

Room 22, Giannini Hall

University of California

Berkeley 4, California

The limit to nonresidents of California is 10 separate issues on a single order. A list of the issues still available will be sent on request. 


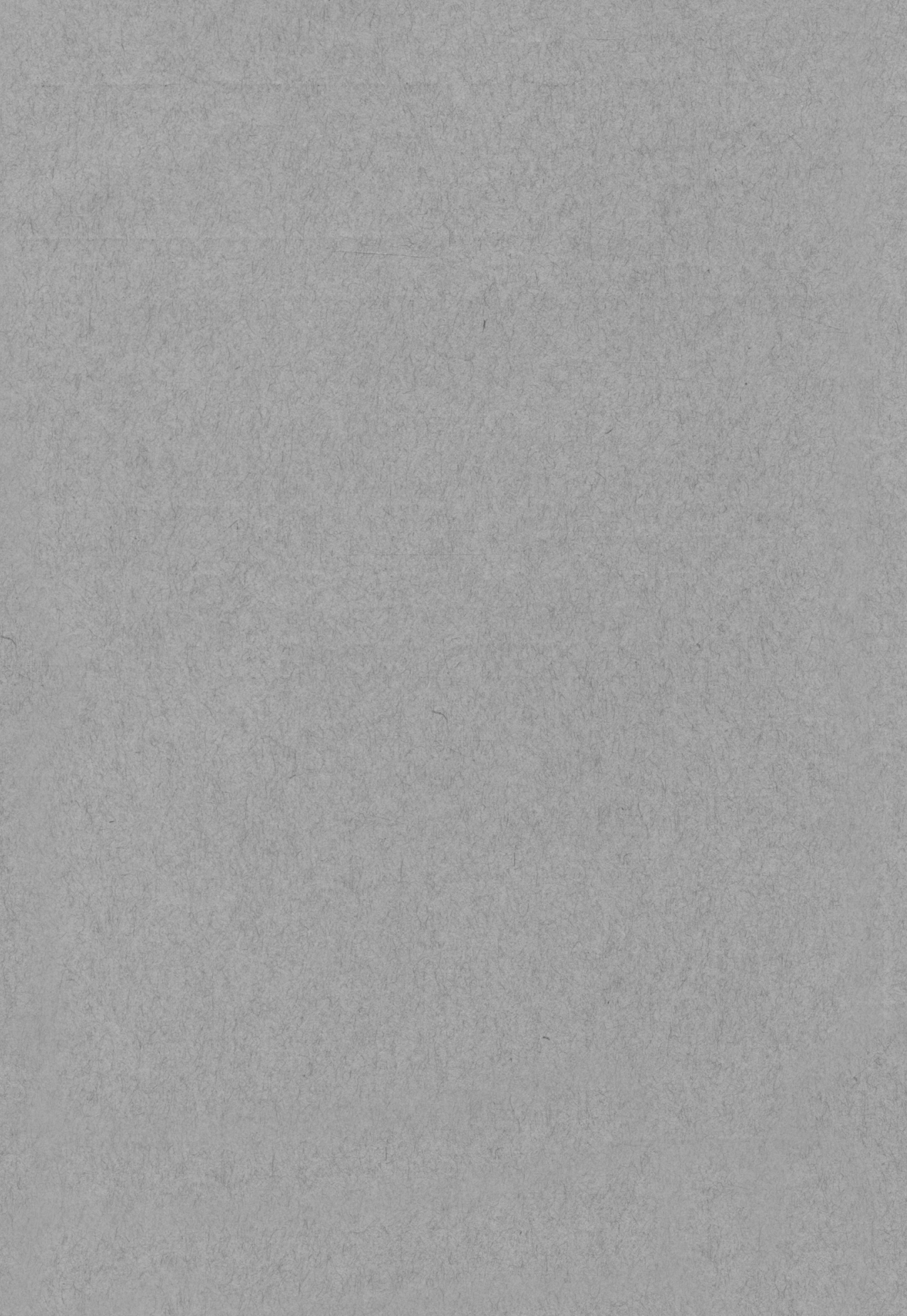

